\title{
Influence of Some Physicochemical Stresses on the Survival of Vibrio cholerae 01 at Non-Culturable State
}

\author{
M Mahfuzul Haque, Sirajul Islam Khan and Chowdhury Rafiqul Ahsan* \\ Department of Microbiology, University of Dhaka, Dhaka 1000, Bangladesh
}

[Received 01 December 2007; Accepted 08 December 2007]

\begin{abstract}
Survival study of toxigenic Vibrio cholerae 01 Classical Inaba and El Tor Ogawa biotypes was carried out in artificial microcosm without any nutrients under stressed physiochemical conditions. The organisms were found to undergo viable but non-culturable (VBNC) state, which was detected by polymerase chain reaction (PCR) technique using primers that flank a specific fragment of the cholera toxin gene (ctx). The findings of the study showed that about $89 \%$ of samples gave positive result although the organisms were in nonculturable state. Depending upon the conditions the Classical biotype of vibrios had undergone non-culturable state within 2-15 days and 55-92 days were subjected to PCR assay after 45 and 120 days of incubation respectively. A similar tend was also observed in case of El Tor biotype. With non-culturable cell only 5 of 18 microcosms (of both Classical and El Tor biotypes) at pH 4.5 showed no viability. Since the PCR assay demonstrated positive results after 90 (in case of El Tor biotype) and 120 days (in case of Classical biotype), the total survival time thus ranges over 3 and 4 months. Thus PCR has an important advantage over the techniques those are used in routine laboratories for the identification of pathogenic organisms.
\end{abstract}

Keywords: Physicochemical stresses, Survivality, Vibrio cholerae, Artificial microcosms, Polymerase chain reaction (PCR), Non-culturable state, Viable but non-culturable (VBNC)

\section{Introduction}

Toxigenic Vibrio cholerae $\mathrm{O} 1$ are able to survive for extended period in water containing no nutrients ${ }^{1}$. During the reduced nutrient levels such as those encountered in aquatic environments ${ }^{2}, V$. cholerae $\mathrm{O} 1$ undergo physiological and morphological changes ${ }^{3}$. Importantly these changes may be related to viable but non-culturable (VBNC) form of V. cholerae O1, which is induced by nutrient deficient environment ${ }^{4}$, and which occur in high concentrations in Bangladesh waters ${ }^{5}$.

Recently laboratory studies have shown that the organism can exist in a VBNC state. Furthermore animal models have demonstrated that such non-culturable cells can regain culturability and remain pathogenic ${ }^{4}$. Since the viable but nonculturable (VBNC) bacteria can not be detected or recovered by standard culture methodology. Thus the survival study of microorganisms by cultural method is not actual study of survivability. Certain pathogens such as Campylobacter sp., Salmonella sp., enteropathogenic Escherichia coli and Vibrio cholerae are reported to enter into VBNC state as a survival strategy during prolonged existence in the aquatic environment and revert to culturable state when optimal favourable conditions exist ${ }^{6}$.
Since Vibrio cholerae are the causative agents of diarrhoea and cholera in Bangladesh and all over the world, their persistence in the environment is a great health concern. The present study had been undertaken to detect VBNC Vibrio cholerae O1 using polymerase chain reaction (PCR).

\section{Materials and Methods}

Microorganisms and artificial microcosms

Two strains of Vibrio cholerae O1, one Classical Inaba (Strain No. 19438) and another one El Tor Ogawa (Strain No. 9710) were used in the study. Survivality of the organisms was carried out in artificial microcosms under stressed conditions such as salinity (0.0, 0.5 and 2.5\%), $\mathrm{pH}(4.5,7.0,8.5$ and 10.0) and temperature (10, 28 and $37^{\circ} \mathrm{C}$ ) for defined period. Viability and the growth of bacterial cells were determined on taurocholate-tellurite-gelatin agar (TTGA) until culturable cells were present in each microcosm. The counting was discontinued when organism could not be recovered on two successive samplings. The non-culturable cells were assessed by the polymerase chain reaction (PCR) technique to determine viable but non-culturable (VBNC) state of the organisms.

\section{PCR assay of Vibrio cholerae O1}

Polymerase chain reaction (PCR) assay was performed for the amplification of the target gene responsible for the synthesis of

*Corresponding author:

Dr. Chowdhury Rafiqul Ahsan, Professor, Department of Microbiology, University of Dhaka, Dhaka 1000, Bangladesh

Tel (Office): (02) 9661920-73, Ext 7738; Tel (Home): (02) 8652011; Fax: +880 (02) 8615583; E-mail: crahsan@yahoo.com 
A-subunit of cholera toxin (ctx). The primers used in this experiment were:

Primer-1 (5'-CTCAGACGGGATTTGTTAGGCACG-3') and Primer - 2 (3'-GCATTATCCCCGATGTCTCTATCT-5').

\section{Preparation of DNA sample}

Microcosm samples (1 $\mathrm{ml})$, in which bacteria had undergone VBNC state, to be amplified were transferred aseptically into a series of 1.5-ml Eppendorf tubes. The tubes were spun down at 14,000 rpm $(16,000 \mathrm{~g})$ for 10 min using an Eppendorf microcentrifuge (Eppendorf, Model No. 5415). The supernatant was discarded and excess $1.0 \mathrm{ml}$ of samples was added to corresponding tubes and was spun down by similar manner. Bacterial pellet was dissolved in $15 \mu \mathrm{l}$ of sterile deionised water and the DNA was extracted by heat-shock or by the method described by Maniatis et al. ${ }^{7}$. The extracted DNA was heated at $96^{\circ} \mathrm{C}$ for 6 min to inactivate proteases and DNases present in the samples, and the DNA extract was stored at frozen condition before using in reaction mixture.

\section{Preparation of reaction mix for setting up in PCR}

For setting up in PCR, $15 \mu \mathrm{l}$ of sample, $2.0 \mu \mathrm{l}$ of primer mix, $15 \mu \mathrm{l}$ of master mix and $18 \mu \mathrm{l}$ of sterile deionised water (total $50 \mu \mathrm{l}$ ) were taken into each corresponding Perkin-Elmer Cetus $0.5-\mathrm{ml}$ GeneAmp reaction tubes, and was mixed gently avoiding generation of bubbles, then span down in a microcentrifuge. To avoid the evaporation the reaction mix was overlaid with 50 to $100 \mu \mathrm{l}$ mineral oil. All the reaction tubes with reaction mix were put into the thermal block of 'Hot Start' DNA Thermal Cycler (Gene Amp PCR System 96000, Perkin-Elmer Cetus Corp. Norwalk, CT 06859), and was allowed for the completion of amplification for 36 cycles. Amplified DNA was stored at $-20^{\circ} \mathrm{C}$ for further analysis.

\section{Analysis of amplified DNA by electrophoresis}

Amplified DNA was electrophoresed on $1.0 \%$ agarose gel containing $0.8 \mu \mathrm{g} / \mathrm{ml}$ of ethidium bromide for 1.5 to $2 \mathrm{~h}$ at 60 volt in Ix TBE running buffer containing $0.8 \mu \mathrm{g} / \mathrm{ml}$ of ethidium bromide.

\section{Detection of DNA}

DNA was visualized by the fluorescence of bound ethidium bromide. Following appropriate running, the gel was removed with the running plate from the main unit and was then transferred on to a black Perspex sheet of uv-transilluminator (Chromato-Vue, TM36, Ultra-Violet products, USA). The fluorescing DNA bands were observed under short wave length of ultra violet light inside of a dark room. The photograph of the gel was carried out using type 55 or type 57 Polaroid film on a Polaroid camera with an orange filter.

\section{Results and Discussion}

Survival of Vibrio cholerae $\mathrm{O} 1$ carried out at different salinity, $\mathrm{pH}$ values and temperatures and the influence of these parameters were monitored up to 70 days (for El Tor strain) and 92 day (for Classical strain). Polymerase chain reaction (PCR) technique was carried out to amplify the target sequence of DNA of both Classical and El Tor biotypes at non-culturable state.

Table 1 represent the survival of $V$. cholerae O1 Classical Inaba (strain No. 19438) at viable but non-culturable (VBNC) state. At
Table 1. Survivality of Vibrio cholerae O1 Classical Inaba biotype (Strain No. 19438) at viable but non-culturable (VBNC) state under different salinities, $\mathrm{pH}$ values and temperatures

\begin{tabular}{|c|c|c|c|}
\hline $\begin{array}{l}\text { Microcosm } \\
\text { (Salinity, \% / } \\
\text { pH / } \\
\text { Temperature, }{ }^{\circ} \mathrm{C} \text { ) }\end{array}$ & $\begin{array}{l}\text { Bacteria undergone } \\
\text { to VBNC state } \\
\text { (Days after } \\
\text { incubation) }\end{array}$ & $\begin{array}{l}\text { PCR done } \\
\text { after days of } \\
\text { undergoing } \\
\text { VBNC state }\end{array}$ & $\begin{array}{l}\text { Results } \\
\text { of PCR }\end{array}$ \\
\hline $0.0 / 4.5 / 10$ & 2 & 43 & - \\
\hline $0.0 / 4.5 / 28$ & 2 & 43 & + \\
\hline $0.0 / 4.5 / 37$ & 2 & 43 & + \\
\hline $0.0 / 7.0 / 10$ & 15 & 30 & + \\
\hline $0.0 / 8.5 / 10$ & 5 & 40 & + \\
\hline 0.0 / 8.5 / 28 & 92 & 28 & + \\
\hline $0.0 / 10.0 / 10$ & 10 & 35 & + \\
\hline $0.5 / 4.5 / 10$ & 2 & 43 & - \\
\hline $0.5 / 4.5 / 28$ & 2 & 43 & + \\
\hline $0.5 / 4.5 / 37$ & 2 & 43 & + \\
\hline $0.5 / 7.0 / 10$ & 15 & 30 & + \\
\hline $0.5 / 7.0 / 37$ & 5 & 40 & + \\
\hline 0.5 / 8.5 / 10 & 15 & 30 & + \\
\hline $0.5 / 10.0 / 10$ & 15 & 30 & + \\
\hline $0.5 / 10.0 / 28$ & 92 & 28 & + \\
\hline 2.5 / 4.5 / 10 & 5 & 40 & + \\
\hline $2.5 / 4.5 / 28$ & 5 & 40 & - \\
\hline 2.5 / 4.5 / 37 & 2 & 43 & + \\
\hline $2.5 / 7.0 / 10$ & 92 & 28 & + \\
\hline $2.5 / 7.0 / 37$ & 92 & 28 & + \\
\hline 2.5 / 8.5 / 10 & 92 & 28 & + \\
\hline 2.5 / 8.5 / 37 & 55 & 65 & + \\
\hline 2.5 / 10.0 / 37 & 55 & 65 & + \\
\hline
\end{tabular}

$\mathrm{pH} 4.5$, Classical strain could survive for more than 30 to 43 days irrespective of salinity and temperature. Only four of 23 microcosms tested showed the extended survival not more than 40 days (Classical strain at $2.5 \%$ salinity, $\mathrm{pH} 4.5$ and at $28^{\circ} \mathrm{C}$ ) and not more than 43 days (Classical strain at $0.0-0.5 \%$ salinity, $\mathrm{pH} 4.5$ and $\left.10^{\circ} \mathrm{C}\right)$.

In case of Classical strain, the cells that undergone to viable but non-culturable (VBNC) state within 55-92 days were subjected to PCR after 120 days of incubation (Figure 1). It was found that Classical vibrios could survive at VBNC state for more than 28 to 65 days at $\mathrm{pH}$ 7.0-10.0 under salinities and temperatures throughout experimental period.

The survivality of V. cholerae O1 El Tor Ogawa (Strain No. 9710) at viable but non-culturable (VBNC) state is summarized in Table 2 . At $\mathrm{pH} 4.5$, El Tor strain could survive for more than 23 days irrespective of salinity and temperature. Only four of 23 microcosms tested showed the extended survival not more than 23 days (El Tor at $0.0 \%$ salinity, $\mathrm{pH} 4.5$ and at $28^{\circ} \mathrm{C}$ ).

In case of El Tor strain, the cells that undergone non-culturable (VBNC) state within 2-5 days and within 10-70 days were subjected to PCR after 25 and 90 days of incubation (Figure 2). It was found that only $\mathrm{pH} 4.5$ at $0.5 \%$ salinity and at $28^{\circ} \mathrm{C}$ supported the extended survival of the organism not more than 23 days. At 


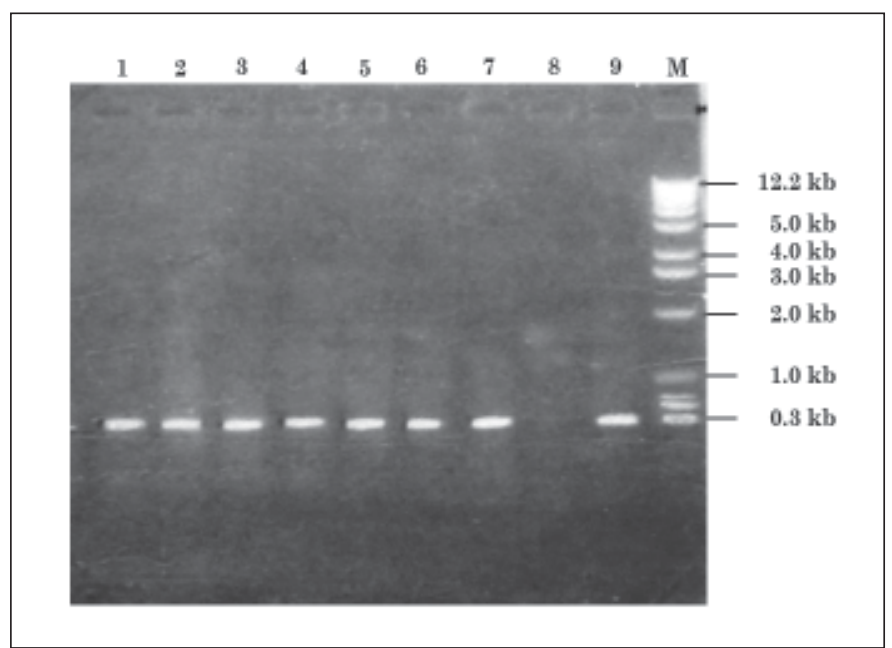

Figure 1. Stained agarose gel showing the PCR amplified DNA targeting the A-subunit of cholera toxin (ctx) of viable but nonculturable (VBNC) state of Vibrio cholerae O1 Classical Inaba (Strain No. 19438). Lane M: DNA ladder used as molecular size marker; Lane 1-7: Amplified DNA samples of Classical Inaba biotype; Lane 8: Negative control; Lane 9: Positive control.

Table 2. Survivality of Vibrio cholerae O1 El Tor Ogawa biotype (Strain No. 9710) at viable but non-culturable (VBNC) state under different salinities, $\mathrm{pH}$ values and temperatures

\begin{tabular}{|c|c|c|c|}
\hline $\begin{array}{l}\text { Microcosm } \\
\text { (Salinity, \% / } \\
\text { pH / } \\
\text { Temperature, }{ }^{\circ} \mathrm{C} \text { ) }\end{array}$ & $\begin{array}{c}\text { Bacteria undergone } \\
\text { to VBNC state } \\
\text { (Days after } \\
\text { incubation) }\end{array}$ & $\begin{array}{l}\text { PCR done } \\
\text { after days of } \\
\text { undergoing } \\
\text { VBNC state }\end{array}$ & $\begin{array}{l}\text { Results } \\
\text { of PCR }\end{array}$ \\
\hline $0.0 / 4.5 / 10$ & 1 & 23 & + \\
\hline 0.0 / 4.5 / 28 & 1 & 23 & - \\
\hline 0.0 / 4.5 / 37 & 1 & 23 & + \\
\hline $0.0 / 7.0 / 10$ & 10 & 80 & + \\
\hline 0.0 / 7.0 / 37 & 5 & 20 & + \\
\hline $0.0 / 7.0 / 28$ & 10 & 80 & + \\
\hline 0.0 / 8.5 / 10 & 10 & 80 & + \\
\hline 0.0 / 8.5 / 28 & 10 & 80 & + \\
\hline 0.0 / 8.5 / 37 & 5 & 20 & + \\
\hline 0.0 / 10.0 / 10 & 10 & 80 & + \\
\hline 0.0 / 10.0 / 28 & 10 & 80 & + \\
\hline 0.0 / 10.0 / 37 & 5 & 20 & + \\
\hline 0.5 / 4.5 / 10 & 5 & 20 & + \\
\hline 0.5 / 4.5 / 28 & 2 & 23 & - \\
\hline 0.5 / 4.5 / 37 & 1 & 23 & + \\
\hline $0.5 / 7.0 / 10$ & 20 & 70 & + \\
\hline $0.5 / 8.5 / 10$ & 70 & 20 & + \\
\hline 0.5 / 10.0 / 10 & 70 & 20 & + \\
\hline 2.5 / 4.5 / 10 & 2 & 23 & + \\
\hline 2.5 / 4.5 / 28 & 2 & 23 & + \\
\hline 2.5 / 4.5 / 37 & 1 & 23 & + \\
\hline $2.5 / 7.0 / 10$ & 25 & 65 & + \\
\hline $2.5 / 8.5 / 10$ & 30 & 60 & + \\
\hline
\end{tabular}

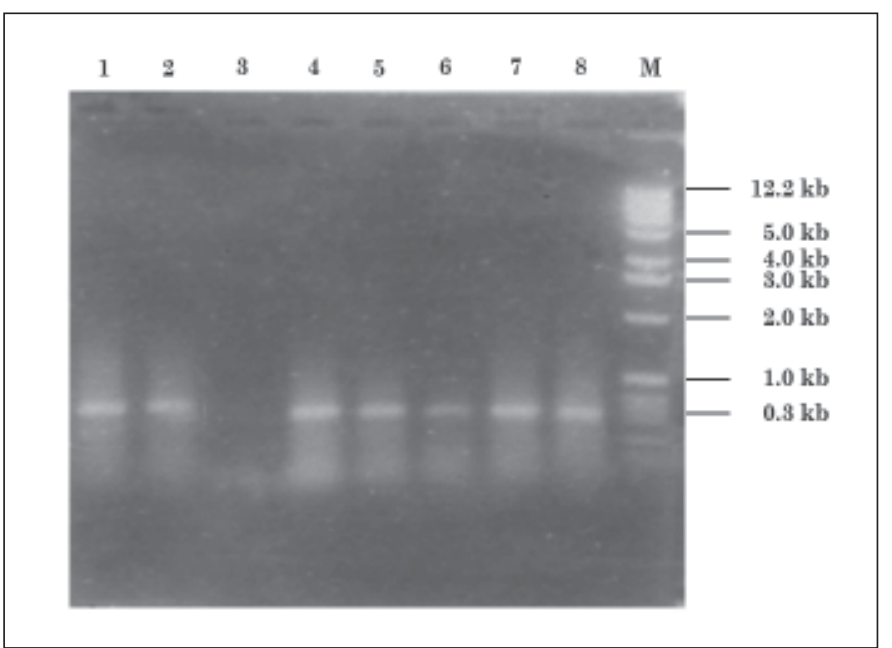

Figure 2. Stained agarose gel showing the PCR amplified DNA targeting the A-subunit of cholera toxin (ctx) of viable but nonculturable (VBNC) state of Vibrio cholerae O1 El Tor Ogawa biotype (Strain No. 9710). Lane M: DNA ladder used as molecular size marker; Lane 1-7: Amplified DNA samples of El Tor Ogawa biotype; Lane 8: Positive control.

other $\mathrm{pH}$ values, regardless of salinity and temperature, seemed to support the extended survival of $V$. cholerae $\mathrm{O} 1$ for more than 20-23 days.

The organisms at $\mathrm{pH}$ value from neutral to alkaline at 10 and $28^{\circ} \mathrm{C}$, and at different salinities could survive at viable but non-culturable (VBNC) state for more than 20 to 80 days (Table 2 and Figure 2). The results thus indicate that the extended survival of $V$. cholerae $\mathrm{O} 1$ for more than 90-120 days (including VBNC), which may meet the interepidemic period between two outbreaks of cholera epidemiology.

A number of species of Gram-negative bacteria have been shown to enter a physiological state at adverse condition and become VBNC and can not be detected by standard culture methods ${ }^{4,8}$. It was reported that non-culturable Vibrio cholerae when ingested by human volunteers, caused clinical symptoms and recovered from stool specimens ${ }^{9}$. Thus the cycle from infected host through a non-culturable state and back to a culturable state in a new host would be completed, and it was obvious that the potential public health hazard presented by such vibrios existing in the nonculturable state may be significant. Since current microbiological culturing methods are unable to detect bacterial cells in nonculturable state, it is important that methods to detect such cells be developed. Further the ability to detect small numbers of cells is essential, as many bacteria are only present in natural environments at low densities. Such detection is especially important for bacteria such as $V$. cholerae $\mathrm{O} 1$, which in certain individual produces rapidly fatal infections. One possible method of detecting such non-culturable cells is the polymerase chain reaction (PCR) that allows amplification of specific segment of DNA obtained from as few as one cell ${ }^{10}$. PCR technique depends only on the presence of target DNA and not on culturable cells, thus PCR is potentially able to detect the presence of VBNC cells. 
It was reported that non-culturable cells remain intact, contained DNA and RNA, bound fatty acids, and show no signs of cell decay that would be expected with non viable cells ${ }^{11-12}$. This finding leads the present study to identify the cholera toxin production is an important step in the diagnosis of cholera, because only toxin producing strains have been associated with severe watery diarrhoea and epidemics. PCR technique was used for the detection of the cholera toxin subunit A gene (ctx A gene) in $V$. cholerae strains, and was applied as a part of a routine identification procedure during survival study. The PCR assay was applied successfully to both bacterial colonies and faecal samples from patients with suspected cholera ${ }^{13-15}$.

The most advantages of PCR over other DNA-based assay methods or immunoassays, is its simplicity and rapidity. During the investigation of outbreak of cholera, the presence of $c t x A$ could be determined within $4 \mathrm{~h}$, whereas enzyme-linked immunosorbent assay (ELISA) requires at least 4 days. Important public health concerns are made on the basis of the PCR data and control strategies are implemented, in some situations within $24 \mathrm{~h}$. The other clear advantage of PCR method over other currently available assay methods is its sensitivity. PCR method is more sensitive, more rapid and easier than the DNA colony hybridization.

It was found throughout the experiments that in 46 of 72 microcosms, i.e., ca. $64 \%$ had undergone to VBNC state, which could not be detected by culturing method. But the PCR assay showed that ca. $89 \%$ of samples was positive although they were non-culturable. PCR gave positive results after 3 and 4 months of incubation (including culturable and non-culturable state), which is almost same as the inter-epidemic period of endemic cholera. Our study has significance over the study of those, which had studied only based on culturable state but not on VBNC state. Thus PCR assay is more suitable for the study of survival strategy.

\section{References}

1. Miller CJ, Drasar BS \& Feachem RG .1984. Response to toxigenic Vibrio cholerae $\mathrm{O} 1$ to physicochemical stresses in aquatic environments $J$ Hyg. 93: 475-495.
2. Baker RM, Singleton FL \& Hood MA. 1983. Effect of nutrient deprivation on Vibrio cholerae. Appl Environ Microbiol. 46: 930-940.

3. Oliver DJ \& Stringer WF. 1984. Lipid composition of psychrophilic marine Vibrio sp. during starvation induced morphogenesis. Appl Environ Microbiol. 47: 461-466.

4. Colwell RR, Brayton PR, Grimes DJ, Roszak DB, Huq SA \& Palmer LM. 1985. Viable but non-culturable Vibrio cholerae and related pathogens in the environment implications for release of genetically engineered microcosms. Biotechnology. 3: 817-820.

5. Brayton PR, Tamplin ML, Huq A \& Colwell RR.1987. Enumeration of Vibrio cholerae O1 in Bangladesh waters by fluorescent-Ab direct viable count. Appl Environ Microbiol. 53: 2862-2865.

6. Rollins DM \& Colwell RR. 1986. Viable but non-culturable stage of Campylobacter jejuni and its role in survival in the natural aquatic environment. Appl Environ Microbiol. 52(3): 531-538.

7. Maniatis T, Fritsch EF \& Sambrook J. 1989. Molecular Cloning: A Laboratory Manual, $2^{\text {nd }}$ edn. Cold Spring Harbor Laboratory, New York.

8. Xu HS, Roberts N, Singleton FL, Attwell RW, Grimes DJ \& Colwell RR. 1982. Survival and viability of non-culturable Escherichia coli and Vibrio cholerae in the estuarine and marine environment. Microb Ecol. 8: 313-323.

9. Colwell RR, Tamplin ML, Brayton PR, Tavgens AL, Tall BD, Herrington D, Levin MM, Hall S, Huq A \& Sack DS. 1990. Environmental aspects of Vibrio cholerae in transmission of cholera. In Advances in Research on Cholera and Related Areas (Sack RB \& Zinnaki R eds), $7^{\text {th }}$ edn, pp 327-343. KTK Scientific Publishers, Tokyo.

10. Steffan RJ \& Atlas RM. 1988. DNA amplification to enhance detection of genetically engineered bacteria in environmental samples. Appl Environ Microbiol. 54: 2185-2191.

11. Morgan JAW, Clarke KJ, Rhodes G \& Pickup RW. 1992. Non-culturable Aeromonas salmonicida in lake water. Microb Releases. 1: 71-78.

12. Margan JAW, Cranwell PA \& Pickup RW. 1991. The survival of Aeromonas salmonicida in lake water. Appl Environ Microbiol. 57: 1777-1782.

13. Shirai H, Nishibuchi M, Ramamurthy T, Bhattacharya SK, Pal SC \& Tekeda Y. 1991. Polymerase chain reaction for detection of cholera enterotoxin operon of Vibrio cholerae. J Clin Microbiol. 29: 25172521.

14. Fields PI, Popovic T, Wachzmuth K \& Olsik O. 1992. Use of the polymerase chain reaction for detection toxigenic Vibrio cholerae O1 strains from the Latin American cholera epidemic. J Clin Microbiol. 30: 2118-2121.

15. Kobayashi K, Set K, Akasaka S \& Makino M. 1990. Detection of toxigenic Vibrio cholerae $\mathrm{O} 1$ using polymerase chain reaction for amplifying the cholera enterotoxin gene. J Jpn Assoc Infect Dis. 64: $1323-1329$. 